\title{
Fuel Choices in Urban Kenyan Households
}

\author{
David Waweru \\ Technical University of Kenya, Kenya
}

\begin{abstract}
In the developing nations of Sub-Saharan Africa, providing households with modern energy services is a critical step towards economic development. A significant proportion of households in Kenya rely on traditional biomass fuels for domestic use. The disadvantages of these fuels are many. Transition to clean fuels such as liquefied petroleum gas or electricity would resolve many of these issues as they do not produce dangerous particulate emissions, and are commercially viable, offering several socio-economic advantages over traditional options. This study applies a multinomial logit model to analyze the fuel choices of cooking fuels in urban Kenyan households. A large microeconomic dataset from Kippra's Comprehensive study on fuel consumption patterns in Kenya is employed during the analysis. The results show that in addition to income, there are several socio-demographic factors such as education and sex of the head of the household, which is important in determining household fuel choice. To encourage clean fuel use, the authorities should carry out public education campaigns and ensure the availability of these fuels in all areas to avoid harmful effects of biomass fuels and kerosene, more modern and efficient appliances should be made available at affordable rates to ensure more efficient use of these forms of energy.
\end{abstract}

Keywords: Fuel Choices, Households, Urban, Energy economics

DOI: $10.7176 / \mathrm{JESD} / 12-14-06$

Publication date:July $31^{\text {st }} 2021$

\section{Introduction}

The switch from traditional biomass fuels to modern, reliable and efficient energy sources has the potential to improve globally the welfare of over 2.5 billion people who continue to depend on unreliable and inefficient biomass fuel for their cooking energy needs (IEA, 2006). Traditional biomass fuels include grass agricultural residue, animal dung, firewood and charcoal. Together with the arduous task of using these fuels, the economic, health and environmental impacts are massive. It is estimated that, due to population growth, about 2.7 billion people who will be a third of the world's population, will depend on biomass fuels for their energy needs by the year 2030 (IEA, 2006).

Health effects due to biomass fuel use are also massive. The World Health Organization identifies the use of solid biomass fuels as one of the major causes to global ill health. In the year 2000, it was estimated that Indoor Air Pollution (IAP) was responsible for more than 1.6 million annual deaths and $2.7 \%$ of the global burden of disease (WHO, 2006). There are various substances in biomass smoke that can damage health such as: Carbon monoxide, sulphur oxides, Nitrogen oxides and various carcinogens such as benzene and formaldehyde (Bruce et al., 2000). Furthermore, the burning of solid biomass fuels also releases small particles into the air, which obstruct airways and lungs and impair immune response (WHO, 2006).

The World Energy Assessment of the United Nations Development Programme (UNDP) analyses the environmental impacts of traditional biomass use under two main categories: Those impacts arising out of the production and harvesting of biomass and those impacts resulting from the combustion of the traditional biomass fuels (UNDP, 2000). Production harvesting of charcoal and fuel wood lead to depletion of forest cover and additional environmental consequences such as carbon stock depletion, erosion, desertification, decreased soil moisture and quality and decreased biodiversity (Schlag \& Zuzarte, 2008).

\subsection{Trends of Energy Consumption in Kenyan Household}

As Kenya pursues its development agenda in the context of a rapidly rising and urbanizing population, the need for timely and reliable data on consumption of energy products and services is necessary (Gisore, 2021). Currently, there are inadequacies in the data and statistical support for energy sector planning, with knowledge on consumption data in terms of consumers by fuel type being weak. Even though the country has several fuel types, there is still lack of knowledge on the factors that drive fuel choice and fuel switching by various consumer categories (Kippra, 2010). Some studies have indicated a number of factors as determinants to the choice of household fuel. Heltberg (2003) found that income of the household and education level of the household head had a very significant negative impact on wood consumption while at the same time encouraging demand for LPG. Ouedraogo (2005) shows that there exist of significant relationships between the use rates of firewood, charcoal and liquefied petroleum gas (LPG) and household size.

The five main sources of fuel for urban Kenyan households are firewood, charcoal, kerosene, LPG and electricity in that order. The various choices available to Kenyan households as well as factors that influence 
these choices is the key aspect in this research as detailed below and in the remaining chapters. Table 1 show the distribution of source of fuel in Kenya.

Table 1: Percentage distribution of households by main source of fuel

\begin{tabular}{|l|c|c|c|}
\hline \multirow{2}{*}{ FUEL TYPE } & \multicolumn{3}{|c|}{ PERCENTAGE } \\
\cline { 2 - 4 } & RURAL & URBAN & NATIONAL \\
\hline Firewood & 87.7 & 10 & 68.3 \\
\hline Grass & 0.1 & 0.2 & 0.1 \\
\hline Charcoal & 7.7 & 30.2 & 13.3 \\
\hline Biomass Residue & 0.4 & 0.1 & 0.3 \\
\hline Kerosene & 2.7 & 44.6 & 13.2 \\
\hline Gas(LPG) & 0.7 & 11.9 & 3.5 \\
\hline Electricity & 0.2 & 1.8 & 0.6 \\
\hline Other & 0.4 & 1.1 & 0.6 \\
\hline TOTAL & 100.0 & 100.0 & 100.0 \\
\hline Population Sampled & $\mathbf{5 , 1 5 5 , 1 0 5}$ & $\mathbf{1 , 7 1 5 , 2 6 9}$ & $\mathbf{6 , 8 6 6 , 3 7 4}$ \\
\hline
\end{tabular}

Source: Kenya Integrated Household Budget Survey (2006).

Accordingly, given the current consumption patterns, sustainable biomass supply is hardly possible. Kamfor's study also predicts a deficit of 0.75 tonnes of biomass fuel per person per year by the year 2020 (Kamfor, 2002). Kenya is faced with environmental problems resulting from deforestation and land degradation (Ouru \& Mose, 2017). This necessitates policy measures being implemented to address the reliance on biomass as an energy source for households in order to reduce the incidence and impact of environmental problems.

\subsection{Statement of the Problem}

Information on fuel choice in urban areas of Kenya is inadequate. There are few studies that focus on fuel choices in any or a number of the urban areas. Osiolo (2009) focuses on determinants of fuel choice and substitution without focus on urban areas whereas Kippra (2010) stops short of determining the importance of each of the factors determining fuel choice. This study aimed to fill this gap by providing information on fuel choice in urban areas. This will assist in revealing the patterns of fuel use and further detail the underlying reasons behind these choices. This will assist in judging how far implementation of policies has resulted in the shift to modern fuel and also assist in policy formulation towards encouragement of households to adopt cleaner fuel types.

\subsection{Objectives of the Study}

The overall objective of this study is to perform an econometric analysis of fuel consumption by urban households in Kenya in order to identify their determinants of fuel choices in major Kenyan urban centre.

\section{Theoretical Literature}

Household fuel choice can be explained using the Energy Ladder model which argues that households with low levels of income rely on biomass fuels, such as wood and dung, while those with higher incomes consume energy that is cleaner and more expensive, such as electricity. Those households in transition-between traditional and cleaner (and more efficient) energy sources - consume what are called transition fuels, such as kerosene and charcoal (Heltberg, 2005). This is explained in the Figure 1 below.

\section{Energy ladder}

\section{Energy stack}

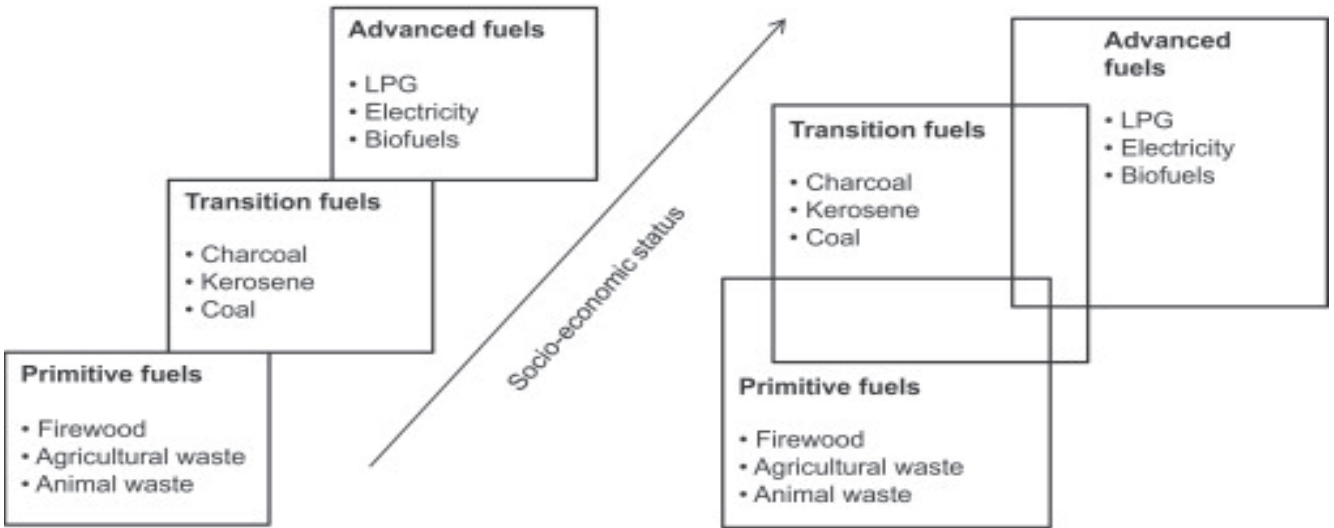

Figure 1: Energy ladder and energy stack models

Source: Schlag et al. (2008) 
More recently, it has been argued that households in developing countries do not switch to modern energy sources but instead tend to consume a combination of fuels, which may include combining solid fuels with nonsolid fuels as sources of energy. Thus, instead of moving up the ladder step by step as income rises, households choose different fuels from a range of fuels. They may choose a combination of high-cost and low-cost fuels, depending on their budgets, preferences, and needs (World Bank, 2003). This led to the concept of fuel stacking (multiple fuel use), as opposed to an energy ladder (Masera et al., 2000; Heltberg, 2005). As in the case of Mexico, as shown in Masera et al. (2000), fuel stacking could be important in urban Kenya because households have limited options for fuel.

\subsection{Empirical Literature Research Gaps}

Numerous studies in developing nations have endeavoured to identify the factors that determine household fuel choice. Some have analysed these factors using econometric techniques and others have done this with descriptive statistics. In Kenya, studies have mainly focused mainly on fuelwood, charcoal and kerosene; LPG and electricity have been left out (Gisore, 2017). Many studies in Kenya have also studied fuel choice in a few urban areas using econometric techniques and none has focused specifically on urban areas. This study intends to focus on fuel choice within urban households in Kenya and will be analysedusing a multinomial logit model with the aim of establishing the factors behind household fuel choice and the importance of each of these factors in determining fuel choice.

\section{Research Methodologies}

\subsection{Model Specification}

The study used multinomial logit model to estimate the significance of the factors believed to influence a household's choice of primary fuel in urban Kenya. Multinomial logit model describes the behaviour of consumers when they are faced with a variety of goods with a common consumption objective. The choice of the model is based on its ability to perform better with discrete choice studies (McFadden, 1974; Judge et al., 1985). However, the goods must be highly differentiated by their individual attributes. For example, the model examines choice between a set of mutually exclusive and highly differentiated fuels such as firewood, charcoal, kerosene, gas, and electricity.

The probability that a household chooses one type of fuel is restricted to lie between zero and one. The model assumes no reallocation in the alternative set and without changes in fuel prices or fuel attributes. The model also assumes that households make fuel choices that maximize their utility (McFadden, 1974). The model can be expressed as follows:

$$
\operatorname{Pr}\left[Y_{i}=j\right]=\frac{\exp \left(\beta^{\prime}{ }_{j} x_{i}\right)}{1+\sum_{j=0}^{\prime} \exp \left(\beta^{\prime}{ }_{j} x_{i}\right)}
$$

Where:

- $\operatorname{Pr}[\mathrm{Yi}=\mathrm{j}]$ is the probability of choosing either firewood, kerosene, gas or electricity with charcoal as the reference household fuel category;

- $\mathrm{J}$ is the number of fuels in the choice set;

- $\mathrm{j}=0$ is firewood;

- $\mathrm{Xi}$ is a vector of the predictor (exogenous) factors(variables)

- $\quad \beta \mathrm{j}$ is a vector of the estimated parameters.

Re-arranging equation 1 , the following is obtained:

$\mathrm{P}_{\mathrm{i}}=\frac{e^{\left(b_{0}+b_{1} x_{1}+b_{2} x_{2}+\cdots b_{n x_{n}}\right)}}{1+e^{\left(b_{0}+b_{1} x_{1}+b_{2} x_{2}+\cdots b_{n x_{n}}\right)}}$

Further re-arrangement using the odds ratio gives the empirical model as:

$\ln \left[\frac{p_{i}}{1-p_{i}}\right]=b_{0}+b_{1} x_{1}+b_{2} x_{2}+\cdots b_{n} x_{n}$

This can also be stated as

$$
\left[\frac{p_{i}}{1-p_{i}}\right]=\mathrm{e}^{\left(\mathrm{b}_{0}+\mathrm{b}_{1} \mathrm{x}_{1}+\mathrm{b}_{2} \mathrm{x}_{2}+\cdots \mathrm{b}_{\mathrm{nx}}\right)}
$$

In equation (3), the quantity $\mathrm{Pi} /(1-\mathrm{Pi})$ is the odds ratio. The equation (3) has expresses the $\operatorname{logit}(\log$ odds) as a 
linear function of the independent factors (Xs). Equation (3) allows for the interpretation of the logit elasticities for variables in the same way as in linear regressions. This equation expresses the odds ratio of selecting a fuel type with respect to the reference category.Differentiating equation (1) we obtain the marginal effects (Greene, 2003).

$\delta_{j}=\frac{\partial P_{j}}{\partial x_{i}}=P_{j}\left(\beta_{j}-\sum_{k=0}^{J} P_{k} \beta_{k}\right)=P_{j}\left(\beta_{j}-\bar{\beta}\right)$

The marginal effects measure the expected change in the probability of choosing one fuel alternative with respect to a unit change in an explanatory variable. For instance, the expected change in probability of choosing a particular fuel type with respect to a one-year change in age of household head. For example, $e^{b 1}$ (in equation 2 ) is the multiplicative factor by which the odds ratio would change if $X_{1}$ changes by one unit.

The model follows from the assumption that the random disturbance terms are independently and identically distributed (McFadden, 1974). In addition, Judge et al., (1985) show that even if the number of alternatives is increased (from 2 to 3 to 4 ) the odds of choosing an alternative fuel remain unaffected. That is, the probability of choosing the particular fuel type remains the same if it is compared to one alternative or if it is compared to two or three or four alternative fuels.

A positivemarginal effect implies an increase in the likelihood that a household will choose the alternative fuel. A negative marginal effect indicates that there is less likelihood that a household will change to alternative fuel. P-value indicates whether or not a change in the predictor significantly changes the logit at the acceptance level. If P-value is greater than the accepted confidence level, then there is insufficient evidence that a change in the predictor affects the choice of response category from reference category.

\subsection{Data Types and Sources}

The study intends to use secondary data from Kippra's comprehensive study and analysis on fuel consumption patterns in Kenya done in 2010. The study focused on the trends in consumption of the various energy products within Kenya. This study utilised a sampling frame created by KNBS (Kenya National Bureau of Statistics) after the 1999 Population Census. This sampling frame consisted of 1,800 clusters, each on average with 100 households, with the aim of conducting socio-economic surveys. Out of 1,800 clusters, 540 of them were urban and 1,260 were rural. Kippra's comprehensive study and analysis on fuel consumption patterns in Kenya (2010) used a 20\% sub-sample of the clusters, resulting in 108 urban clusters and 252 rural clusters. Traditionally, KNBS has randomly selected 10 households in each cluster for any study. Therefore, 1,080 urban households and 2,520 rural households were interviewed. For the purpose of this study, only the urban households totalling 1080 were considered. The sample of clusters was allocated to the districts using the relative household strength of the district within a province. This minimised bias in the selection of the household clusters. The study also interviewed 857 energy providers.

\subsection{Definition and Measurement of Variables}

The study will focus on a number of variables that affect household fuel choice. The endogenous variables are the various fuel types available to urban Kenyan households. Table 2 shows the measure and definition of variables.

Table 2: Variables included in the model and their measurement

\begin{tabular}{|c|c|c|c|c|c|}
\hline Variable & Listing & Measurement & $\begin{array}{l}\text { Model } \\
\text { Listing }\end{array}$ & $\begin{array}{l}\text { Expected } \\
\text { Size }\end{array}$ & Study that shows result \\
\hline $\begin{array}{l}\text { Household } \\
\text { Expenditure } \\
\text { Energy Type }\end{array}$ & $X_{1}$ & $\begin{array}{l}\text { Continous in } \\
\text { Kenya Shillings }\end{array}$ & $\begin{array}{l}\text { Cost } \\
\text { month }\end{array}$ & $\begin{array}{l}\text { Ksh } 50.00- \\
35,000.00 .\end{array}$ & Osiolo (2009), Kippra (2010) \\
\hline $\begin{array}{ll}\text { Gender } & \text { of } \\
\text { household Head }\end{array}$ & $X_{2}$ & $\begin{array}{l}\text { Binary } \\
1=\text { Male } ; 0=\text { Other }\end{array}$ & Gender & 1 or 0 & Osiolo (2009) \\
\hline Household Size & $X_{3}$ & $\begin{array}{l}\text { Continous } \\
\text { Number }\end{array}$ & $\begin{array}{l}\text { Hh } \\
\text { member }\end{array}$ & $1-19$ & $\begin{array}{l}\text { Ouedraogo(2005), Mekonnen } \\
\text { and Kohlin (2009). }\end{array}$ \\
\hline $\begin{array}{l}\text { Age of Household } \\
\text { Head }\end{array}$ & $X_{4}$ & $\begin{array}{l}\text { Continous } \\
\text { Number }\end{array}$ & Age head & $18-90$ & Osiolo(2009), Kippra(2010) \\
\hline Education of Head & $X_{5}$ & $\begin{array}{l}\text { Continous } \\
\text { Number }\end{array}$ & Education & $\begin{array}{l}\text { Years: } \\
1-21\end{array}$ & $\begin{array}{l}\text { Ouedraogo(2005), Mekonnen } \\
\text { and Kohlin(2009) }\end{array}$ \\
\hline Household income & $X_{6}$ & $\begin{array}{l}\text { Income in Kenya } \\
\text { Shillings. }\end{array}$ & Income & $\begin{array}{l}\text { Kshs } 1000.00 \\
-300,000.00\end{array}$ & Kebede (2002) \\
\hline
\end{tabular}

These include: firewood charcoal, kerosene, LPG and electricity. In the model, the probability of choosing each fuel type is what estimated using multinomial logit model was. 


\section{Findings and Discussions}

4.1 Descriptive statistics

Table 3 shows the trend and economic properties of study variables.

Table 3: Variables and their properties

\begin{tabular}{llllll}
\hline Variable & Observations & Mean & Std.Dev & Min & Max \\
\hline Fuel type & 1170 & 2.15641 & 1.302881 & 0 & 5 \\
Cost Month & 1170 & 1044.164 & 1629.412 & 50 & 34000 \\
HH Members & 1170 & 4.300855 & 2.299273 & 1 & 15 \\
Income & 1170 & 28607.05 & 34898.35 & 1250 & 250000 \\
Education & 1170 & 13.65299 & 4.143606 & 1 & 21 \\
Age head & 1170 & 36.4906 & 11.06861 & 24 & 80 \\
Gender & 1170 & 0.232479 & 0.422593 & 0 & 1 \\
\hline
\end{tabular}

The average number of household members was 4 while the average level of education was 13.6 years which translates to a diploma level education. The average income of Ksh 28607.05 could have been skewed upwards by the high income earners some who earned above Ksh 200,000.00. Majority of the household heads were male which is $76.7 \%$ of the total households. The average cost spent on the main source of fuel was slightly above Ksh 1000.00 .

Table 4 shows the Multinomial logit regression results for main choice of fuels

Table 4: Multinomial logit regression results for main choice of fuels

\section{Multinomial Logistic Regression}

Observations

LR chi2(30)

1170

686.11

$-1441.0952$

LogLikelihood $=$

\begin{tabular}{|c|c|c|c|c|c|c|}
\hline \multirow{2}{*}{\begin{tabular}{|l|} 
Variable \\
Firewood
\end{tabular}} & \multirow[t]{2}{*}{ Coeff } & \multirow[t]{2}{*}{ Std Error } & \multirow[t]{2}{*}{$\mathbf{z}$} & \multirow[t]{2}{*}{$\mathbf{P}>\mathbf{I z I}$} & \multicolumn{2}{|c|}{ 95\%Conf Interval } \\
\hline & & & & & & \\
\hline CostMonth & -0.0003412 & 0.0002562 & -1.33 & 0.183 & -0.0008434 & 0.0001611 \\
\hline HHMembers & 0.1007519 & 0.0534103 & 1.89 & 0.059 & -0.0039303 & 0.2054341 \\
\hline Income & -0.0000324 & 0.0000127 & -2.56 & 0.010 & 5.73E-05 & 7.63E-07 \\
\hline Education & -0.0501595 & 0.0289627 & -1.73 & 0.083 & -0.1069253 & 0.0066063 \\
\hline Agehead & 0.0494663 & 0.0111197 & 4.45 & 0.000 & 0.0276721 & 0.0712606 \\
\hline Gender & -0.0296644 & 0.02985073 & -0.10 & 0.921 & -0.6147279 & 0.5553992 \\
\hline cons & -2.7673550 & 0.6255705 & -4.42 & 0.000 & -3.99345 & -1.541259 \\
\hline Charcoal & Base Outcome & & & & & \\
\hline \multicolumn{7}{|l|}{ Kerosene } \\
\hline CostMonth & 0.0001212 & 0.0001757 & 0.69 & 0.049 & -0.0002233 & 0.0004656 \\
\hline HHMembers & -0.3433989 & 0.0528918 & -6.49 & 0.000 & -0.4470648 & -0.239733 \\
\hline Income & -0.0000023 & 0.00000874 & -0.26 & 0.799 & -0.0000193 & 0.0000149 \\
\hline Education & 0.0010901 & 0.0250202 & 0.04 & 0.965 & -0.0479485 & 0.0501287 \\
\hline Agehead & 0.0032959 & 0.0093427 & 0.35 & 0.724 & -0.0150153 & 0.0216072 \\
\hline Gender & 0.0991872 & 0.2096825 & 0.47 & 0.636 & -0.311783 & 0.5101574 \\
\hline cons & 0.4754173 & 0.4506887 & 1.05 & 0.291 & -0.4079163 & 1.358751 \\
\hline \multicolumn{7}{|l|}{ LPG } \\
\hline CostMonth & 0.0004622 & 0.0001545 & 2.99 & 0.003 & 0.0001593 & 0.000765 \\
\hline HHMembers & -0.3286171 & 0.0541352 & -6.07 & 0.000 & -0.4347202 & -0.222514 \\
\hline Income & 0.0000612 & 0.00000662 & 9.25 & 0.000 & 0.0000483 & 0.0000742 \\
\hline Education & 0.1599729 & 0.0304021 & 5.26 & 0.000 & 0.1003858 & 0.21956 \\
\hline Agehead & 0.0099139 & 0.0101919 & 0.97 & 0.331 & -0.100619 & 0.0298897 \\
\hline Gender & 0.1451255 & 0.231866 & 0.63 & 0.531 & -0.3093235 & 0.5995744 \\
\hline cons & -3.737455 & 0.5743894 & 6.51 & 0.000 & -4.863237 & -2.611673 \\
\hline \multicolumn{7}{|l|}{ Electricity } \\
\hline CostMonth & 0.0008431 & 0.0001464 & 5.76 & 0.000 & 0.0005561 & 0.0011301 \\
\hline HHMembers & -0.3190949 & 0.0530683 & -6.01 & 0.000 & -0.4231069 & -0.215083 \\
\hline Income & 0.0000575 & 0.00000663 & 8.67 & 0.000 & 0.0000445 & 0.0000704 \\
\hline Education & 0.1434382 & 0.0293707 & 4.88 & 0.000 & 0.0858726 & 0.2010037 \\
\hline Agehead & -0.0159312 & 0.0104811 & -1.52 & 0.129 & -0.0364739 & 0.046115 \\
\hline Gender & 0.1927495 & 0.2273186 & 0.85 & 0.396 & -2527868 & 0.6382858 \\
\hline cons & -2.789678 & 0.5450435 & -5.12 & 0.000 & -3.857943 & -1.721412 \\
\hline
\end{tabular}

0.0000

0.1923 


\begin{tabular}{lrrrrrr}
\hline Variable & Coeff & \multicolumn{2}{c}{ Std Error } & \multicolumn{1}{c}{$\mathbf{z}$} & P>IzI & \multicolumn{2}{c}{ 95\%Conf Interval } \\
\hline Residues & & & & & & \\
CostMonth & 0.0004595 & 0.006737 & 0.68 & 0.050 & -0.0008609 & 0.0017799 \\
HHMembers & -0.2366082 & 0.2402668 & -0.98 & 0.325 & -0.7075226 & 0.2343061 \\
Income & 0.00000603 & 0.0000403 & 0.15 & 0.881 & -0.0000729 & 0.0000849 \\
Education & 0.0203924 & 0.1252294 & 0.16 & 0.871 & -0.2250526 & 0.2658374 \\
Agehead & 0.0667684 & 0.0367777 & 1.82 & 0.069 & -0.0053144 & 0.1388513 \\
Gender & 1.168159 & 1.030996 & 1.13 & 0.257 & -0.8525566 & 3.188874 \\
cons & -7.375567 & 2.641407 & -2.79 & 0.005 & -12.55263 & -2.198505 \\
\hline
\end{tabular}

The results of the multinomial regression above reveal the following: The base category was charcoal and this could have been because more residents used charcoal in urban areas due to its availability and it was relatively cleaner and easier to use than firewood. Thus, the comparisons of the fuel were all compared to charcoal as the base category.

Seven percent of households chose firewood as their main source of fuel. The coefficients for firewood were negative for monthly cost income and education and this implied as one or more of these factors increased the probability that one chooses firewood over charcoal decreased. If the household head was male, the lower the probability for him to choose firewood over charcoal. An older household head and or a large household increased the probability that the household chose firewood over charcoal as its main source of fuel.

Almost twenty percent of households chose kerosene as their main source of fuel. The factors that led to an increase in probability that a household would select kerosene over charcoal include lower household members, increased years of education, increased monthly cost, increased age of household head and male household head. An interesting finding was an increase in income led to a decrease in probability that one would choose kerosene over charcoal; this however, was of very low significance.

LPG and electricity were also found to be popular among the residents. The most significant factors that encouraged households to either of them over charcoal are: increased monthly cost of fuel, increased income, more years of education, male household head and a smaller household. However, an older household head meant an increase in the probability that one would choose LPG over charcoal but a decrease in the probability that one would choose electricity over charcoal.

\section{Conclusions and Recommendations}

This study applied logit model to determine the odds ratio of selecting clean versus unclean fuel as the main household fuel choice and multinomial logit model and investigated factor estimates on choices of cooking fuel in urban Kenyan households. A large microeconomic dataset from KIPPRA's Comprehensive study and Analysis on fuel consumption patterns in Kenya (2010) was employed to carry out the analysis. This study also undertook to establish the coefficients of the factors determining household fuel choice. The most significant factors were found to be the number of members in the household and years of education of household head. The factors most significant in determining household fuel choice include years of education of the household head and number of members of the household. In conclusion the study established that in addition to income, there are several socio-demographic factors such as education and sex of the head of the household, were important in determining household fuel choice.

Due to the fact that some households still used firewood as their main choice of fuel, it would be advisable to encourage use of more efficient wood stoves. Education on the availability and benefits of these stoves will go a long way in ensuring that these stoves are utilized effectively. Effective use will result in a decreased demand for firewood. This will minimize the environmental impacts of firewood use. It will also ensure households suffer less from indoor air pollution since the burning of the firewood will be more efficient thus produce less smoke.

Education on the benefits of clean energy to the environment and to health of household members should be emphasized. This will ensure majority of the population know the harmful effects of unclean energy and make informed decisions on choice of fuel for household use.

\subsection{Areas for Further Research}

The study focused on the main fuel choice within urban centers. Further research may focus on the second and third fuel option used in households.

\section{References}

Bruce, N., Perez-Padilla, R., and Albalak, R. (2000). Indoor air pollution in developing countries: A major environmental and public health challenge. Bulletin of the World Health Organization, 78, 1078-1092.

Cecelski, E. (1987). Fuel and rural women's work: Crisis, response and public alternatives. International Labour Review, 126 (January-February), 41-63. 
Cuthbert, A. L., \& Dufournaud, C.M. (1998). An econometric analysis of fuel consumption in Sub-Saharan Africa. Environment and Planning, 30,721-729.

Ezzati, M., \& Kammen, D. M. (2001). Indoor air pollution from biomass combustion and acute respiratory infections in Kenya: An Exposure-Response Study. The Lancet, 358(9282), 619-24.

Gisore, N. (2017). Renewable energy and nonrenewable energy consumption, $\mathrm{co}_{2}$ emissions and economic expansion nexus: Further evidence from Kenya. Energy Economics Letters, 4(4), 36-48

Gisore, M. (2021). Determinants of regional economic growth in Kenya. African Journal of Business Management, 15(1), 1-12

Greene, W.H. 2003.Econometric analysis.5th ed. Prentice Hall-Pearson Education International.

Gangopadhyay, S., Ramaswami, B.,\&Wadhwa, W. (2003): Access of the poor to modern household fuels in India.SERFA Report for the World Bank.

Heltberg, R. (2003).Household fuel and fuel use in developing countries a multicounty study.Oil and Gas Division, World Bank, Washington DC.

Heltberg, R., (2005). Factors determining household fuel choice in Guatemala. Environmental and development economics 10, 337-61.

Heltberg, R., Arndt, T. C., \& Sekhar, N. U. (2000). Fuel-wood consumption and forest degradation: A household model for domestic fuel substitution in rural India. Land Economics, Vol. 76 No. 2. pp. 213-232.

IEA (International Fuel Agency), (2006). World fuel outlook. Paris: OECD.

Judge, G.G., Hill, R.C., Griffiths, W.E., Lütkepohl, H., \& Lee, T.C. (1985).Theory and Practice of Econometrics. John Wiley and Sons, New York.

Kamfor, (2002). Study on Kenya's energy demand, supply and policy strategy for households, small scale industries, and service establishments. Final Report. Ministry of Energy.

Karekezi, S.,\&Kithyoma, W. (2005). Sustainable energy in Africa: Cogeneration and Geothermal in the East and Horn of Africa - Status and Prospects, Nairobi, AFREPREN/FWD.

Kebede, E., Kagochi, J., \& Jolly, C.M., (2010). Fuel consumption and economic development in Sub-Sahara Africa. Fuel economics 32(3), 532-537.

Karekezi, S., (2002), Poverty and energy in Africa - A brief review. EnergyPolicy,30, (2002): 915-919.

KIPPRA, (2010). A comprehensive study and analysis on fuel consumption patterns in Kenya" Nairobi.

Macht, C., Axinn, W., \& Ghimire, D., (2007). Household Energy Consumption:Community Context and the Fuelwood Transition, Michigan: Populations Studies Centre University of Michigan.

Masera, O.R., Saatkamp, S.D. \& Kammen, D.M (2000). From linear fuel switching to multiple cooking strategies: A critique and Alternative to Fuel Ladder Model. World Development, 28(12), 2083 -2103.

Masera, Reddy, B.S. (1995). A multinomial logit model for fuel shifts in the domestic sector. Fuel, 20(9), 929936.

McFadden, D. (1974). Conditional logit analysis of qualitative choice behaviour. Economic Theory and Mathematical Economics. Academic Press, New York.

Mekonnen, A., and Kohlin, G. (2009). Determinants of household fuel choice in major cities in Ethiopia.Working Papers in Economics No 399, University of Gothenburg, Sweden.

Nyembe, M., (2011).An econometric analysis of factors determining charcoal consumption by urban households: The case of Zambia. Unpublished masters Thesis, Uppsala

Ouedraogo, B., (2006). Householdfuel preferences for cooking in urban Ouagadougou Burkina Faso.Fuel policy 34, 3787-3795.

Ouru, L., \& Mose, N. (2017). The Interactive effect of agricultural input, and research and development on agricultural sector expansion. Asian Development Policy Review, 5(4), 262-271

Pundo, M.O and Fraser, G. (2006). "Multinomial logit analysis of household cooking fuel choice in rural Kenya: The case of Kisumu District" Agrekon, Vol 45.No 1.

Republic of Kenya. (Various Issues). Economic survey. Nairobi: Government Printer.

Osiolo, H. (2009). Enhancing household fuel choice and substitution in Kenya, Kippra Discussion Paper no 102.

Schlag, N., \&Zuzarte, F, (2008). Market barriers to clean cooking fuels in Sub-Saharan Africa: A Review of Literature. Working paper, Stockholm Environment Institute.

United Nations Development Programme. (2000).World energy assessment: Energy and the challenges of sustainability. New York, United Nations Development Programme.

Varian, H.R. (1996). Intermediate microeconomics: A Modern Approach; W.W Norton and Company, New York London.

World Health Organization, (2006). Fuel for life: Household energy and health Geneva.

WHO.http://www.who.int/indoorair/publications/fuelforlife.pdf

World Bank. (2003).Household fuel use in developing countries: A Multicounty Study. ESMAP Technical Paper, no. 042. Washington, DC: World Bank. 